\title{
Drivers of soil respiration in response to nitrogen addition in a Mediterranean mountain forest
}

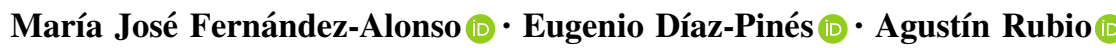

Received: 12 October 2020/Accepted: 23 June 2021 / Published online: 13 July 2021

(C) The Author(s) 2021

\begin{abstract}
Atmospheric nitrogen (N) deposition rates affect soil $\mathrm{N}$ dynamics, influencing soil respiration $\left(\mathrm{R}_{\mathrm{S}}\right)$ rates. However, for the Mediterranean region, the effect of changes in atmospheric $\mathrm{N}$ deposition on $\mathrm{R}_{\mathrm{S}}$ are not well constrained yet. We investigated the interplay between increased $\mathrm{N}$ deposition and tree species composition on $\mathrm{R}_{\mathrm{S}}$ at a Scots pine-Pyrenean oak ecotone in Central Spain, and whether the observed responses were mediated by changes on
\end{abstract}

Responsible Editor: Melanie A. Mayes.

Supplementary Information The online version contains supplementary material available at https://doi.org/10.1007/ s10533-021-00827-2.

M. J. Fernández-Alonso · A. Rubio

Departamento de Sistemas y Recursos Naturales, Universidad Politécnica de Madrid (UPM), Ciudad Universitaria s/n, 28040 Madrid, Spain

e-mail:mj.fernandez@upm.es

A. Rubio

e-mail: agustin.rubio@upm.es

M. J. Fernández-Alonso

Departamento de Ciências da Vida, Centro de Ecologia Funcional, Universidade de Coimbra, Calçada Martim de Freitas, 3000-456 Coimbra, Portugal

E. Díaz-Pinés $(\square)$

Institute of Soil Research, University of Natural

Resources and Life Sciences, Vienna (BOKU), Peter-

Jordan-Straße 82, 1190 Vienna, Austria

e-mail: eugenio.diaz-pines@boku.ac.at selected soil properties. Throughout 3 years, we simulated two $\mathrm{N}$ deposition rates-10 (medium) and $40 \mathrm{~kg} \mathrm{~N} \mathrm{ha}^{-1} \mathrm{a}^{-1}$ (high)—over the background deposition (control) in neighbouring stands in which tree species composition (pine or oak) shapes soil stoichiometry and microbial communities. We monitored $\mathrm{R}_{\mathrm{S}}$ on a monthly basis during 3 years; in addition, we performed targeted measurements $24 \mathrm{~h}$ after the $\mathrm{N}$ fertilization events to assess short-term soil responses. During winter and summer, $\mathrm{R}_{\mathrm{S}}$ did not respond to enhanced $\mathrm{N}$ deposition rates. In spring and autumn, higher $R_{S}$ rates were observed in the medium-fertilization, but the size and duration of this effect was tree species dependent. We suggest that climate seasonality modulates the response of $\mathrm{R}_{\mathrm{S}}$ to $\mathrm{N}$ availability, with tree species effects becoming relevant only when environmental conditions are adequate. $\mathrm{R}_{\mathrm{S}}$ in fertilized plots was larger from February to May and in September under pine, while under oak a response was observed only in April, probably due to differences in native soil stoichiometry under each tree species. Overall, $\mathrm{R}_{\mathrm{S}}$ showed high stability during 3 years of $\mathrm{N}$ enrichment in this Mediterranean ecotone area. However, we observed short-term soil responses after $\mathrm{N}$ fertilization events-loss of base cations, soil acidification and reduced microbial biomass - which emphasize the need to investigate consequences for the belowground $\mathrm{C}$ and $\mathrm{N}$ cycles if chronic $\mathrm{N}$ enrichment persists in the long run. 
Keywords Atmospheric nitrogen deposition . Ecotone forests $\cdot$ Soil acidification $\cdot$ Soil microbial biomass $\cdot$ Soil $\mathrm{CO}_{2}$ efflux $\cdot$ Carbon use efficiency

\section{Introduction}

The use of fossil fuels and nitrogen $(\mathrm{N})$ fertilizers for agricultural production has significantly increased the transfer rate of reactive $\mathrm{N}$ from the atmosphere to terrestrial ecosystems (Galloway et al. 2008), having a cascade of effects (Galloway et al. 2003; Sutton et al. 2011) on, for example, biodiversity (Bobbink et al. 2010), eutrophication (Bouwman et al. 2002) or air quality and human health (Galloway et al. 2008). In $\mathrm{N}$-limited forests, enhanced atmospheric $\mathrm{N}$ deposition usually increases plant growth and soil carbon (C) stocks through the slowdown of litter and soil organic matter decomposition (Pregitzer et al. 2008; de Vries et al. 2009; Janssens et al. 2010). In forests where $\mathrm{N}$ saturation thresholds (Aber et al. 1998) are surpassed-i.e. when $\mathrm{N}$ availability exceeds ecosystem $\mathrm{N}$ demand, further increases in $\mathrm{N}$ input rates may lead to soil acidification, biodiversity loss and leaching of base cations (Bobbink et al. 2010). The tightly coupling between the $\mathrm{C}$ and $\mathrm{N}$ biogeochemical cycles may lead to important variations in the aboveground and belowground $\mathrm{C}$ cycle in response to increased $\mathrm{N}$ deposition (Gruber and Galloway 2008), affecting bulk soil respiration $\left(\mathrm{R}_{\mathrm{S}}\right)$ in both its autotrophic and heterotrophic components (Janssens et al. 2010).

Several meta-analyses have addressed the effects of increased $\mathrm{N}$ deposition on $\mathrm{R}_{\mathrm{S}}$ among forest biomes, with overall results showing a decline (Janssens et al. 2010; Zhou et al. 2014; Zhong et al. 2016). Nitrogen addition may reduce $R_{S}$ rates through three main mechanisms: (1) declined rhizosphere activity with reduced plant belowground $\mathrm{C}$ allocation in favour of aboveground tissue production (Pregitzer et al. 2008; de Vries et al. 2009), (2) changes in the abundance, composition and/or activity of soil saprophytic communities (Frey et al. 2004; Treseder 2008), which in turn influence the microbial carbon use efficiency (CUE; Liu et al. 2018), and (3) soil organic matter stabilization via soil acidification and chemical protection (Janssens et al. 2010; Averill and Waring 2018). However, these response patterns are not universal, since other competing mechanisms-e.g. alleviation of microbial $\mathrm{N}$ limitation or stimulation of photosynthesis - may positively impact $R_{S}$ (Högberg et al. 2006). Further, $\mathrm{N}$ turnover processes are highly sensitive to variations in soil moisture and temperature regimes (Dirnböck et al. 2017), which may also have contributed to the observed discrepancies in the effects of $\mathrm{N}$ addition on $\mathrm{R}_{\mathrm{S}}$. There is an interplay between $\mathrm{N}$ deposition effects and climate constrains affecting plant and microbial activities (Zhou et al. 2014; Zhong et al. 2016). As a result, the specific role of biotic and abiotic processes in inducing changes in $R_{S}$ remains elusive (Waldrop and Zak 2006; Riggs and Hobbie 2016). In addition, in Mediterranean regions dry $\mathrm{N}$ deposition dominates and $\mathrm{N}$ accumulates on soil and plant surfaces during drought periods; when rainfall comes, $\mathrm{N}$ availability suddenly increases in the soil and these $\mathrm{N}$ flushes are decoupled from plant physiological demand (Fenn et al. 2003; Ochoa-Hueso et al. 2011). Overall, there is limited evidence of $\mathrm{N}$ deposition impacts on soil properties under the specificities of the Mediterranean ecosystems, impeding a robust prediction of the $R_{S}$ response.

Tree species composition is an additional player in the effect of rising $\mathrm{N}$ deposition on belowground $\mathrm{C}$ cycling, since trees strongly shape the soil system through the biochemistry of detritus inputs, microbial community, $\mathrm{pH}$, nutrient availabilities and mineralization processes (Bobbink et al. 2010; Zhong et al. 2016; Averill and Waring 2018). In the broadleavedconiferous ecotone forests of Pyrenean oak (Quercus pyrenaica Willd.) and Scots pine (Pinus sylvestris L.) in Central Spain, tree species composition leads to marked differences in soil $\mathrm{pH}$, nutrient stoichiometry and C decomposability (Díaz-Pinés et al. 2011b; Fernández-Alonso et al. 2018a; Table 1). These differences indicate that pine stands generate a more oligotrophic environment in which $\mathrm{N}$ is strongly limiting. Furthermore, forest successional changes are currently taking place as a result of global change favouring an upwards expansion of the Pyrenean oak distribution at the expense of Scots pine (Galiano et al. 2010; Ruiz-Labourdette et al. 2012; Moreno-Fernández et al. 2016). However, there is a gap in our current understanding of the interactive effects between some aspects of global change-e.g. increased $\mathrm{N}$ deposition and forest composition shifts—on belowground $\mathrm{C}$ dynamics in Mediterranean ecosystems. In this sense, different physiological tree responses are likely to yield different outcomes upon environmental stressors 
in soils (Sher et al. 2004; Ochoa-Hueso et al. 2011). The development of this knowledge will also be relevant to understand the functioning of forest soils in other geographical areas under Mediterranean climate, namely the Mediterranean basin, California (USA) and Baja California (Mexico), where oak and pine forests are dominant elements.

We conducted a multi-level manipulation experiment simulating an increase in atmospheric $\mathrm{N}$ deposition at the altitudinal contact between Scots pine and Pyrenean oak forests in Central Spain. This Mediterranean region is affected by $\mathrm{N}$ pollutant mainly from metropolitan areas and livestock production (OchoaHueso et al. 2011; Escudero et al. 2016). Throughout 3 years, we applied 0 (control), 10 (medium) and $40 \mathrm{~kg} \mathrm{~N} \mathrm{ha}^{-1} \mathrm{a}^{-1}$ (high) as wet deposition over the $10-15 \mathrm{~kg} \mathrm{~N} \mathrm{ha}^{-1} \mathrm{a}^{-1}$ of background atmospheric $\mathrm{N}$ deposition (García-Gómez et al. 2014). We combined $\mathrm{R}_{\mathrm{S}}$ measurements and annual soil samplings performed $24 \mathrm{~h}$ after the $\mathrm{N}$ fertilization events (i.e. shortterm response) with monthly $R_{S}$ measurements.

Our specific objectives were to (1) quantify the impact of enhanced $\mathrm{N}$ deposition rates on $\mathrm{R}_{\mathrm{S}}$; (2) elucidate whether tree-species composition control the observed differences; (3) evaluate the response of soil chemical and biological attributes to the $\mathrm{N}$ flushing events originated by the rains in Mediterranean regions; and (4) explore the causal relationships among soil attributes and determine how they may be affected in the short-term by $\mathrm{N}$ fertilization events. We hypothesized that (i) increased $\mathrm{N}$ deposition will negatively affect $R_{S}$ rates, with larger effects for high N inputs (Janssens et al. 2010; Zhou et al. 2014; Zhong et al. 2016). We anticipated (ii) a high temporal variability in the response of $\mathrm{R}_{\mathrm{S}}$ to $\mathrm{N}$ additions driven by the marked seasonality of the Mediterranean climate. Further, we expected that (iii) $\mathrm{R}_{\mathrm{S}}$ under pine will show higher sensitivity to $\mathrm{N}$ inputs than under oak, based on the oligotrophic soil environment under pine compared to the copiotrophic soil environment under oak. Finally, we hypothesized that (iv) increases in soil $\mathrm{N}$ availability will reduce microbial biomass and soil $\mathrm{pH}$ in the short-term, as it has been generally observed in forests (Zhou et al. 2014; Riggs and Hobbie 2016).

\section{Material and methods}

\section{Study site}

The study was carried out in Valsaín Mountains, in the northern slopes of the Guadarrama Range (Central Spain, $40^{\circ} 51^{\prime} \mathrm{N}, 4^{\circ} 3^{\prime} \mathrm{W}$ ) at $1350 \mathrm{~m}$ above sea level, where the altitudinal belts of pure Pyrenean oak and pure Scots pine forests overlap. The current composition and structure of the forests are the result of an intense and lasting human management; tree species distributions are shifting in the last decades because of global change drivers, namely climate and land management (Moreno-Fernández et al. 2016). These mountains are affected by air pollution in form of $\mathrm{NO}_{\mathrm{x}}$ originated from highways and urbanization (e.g. Segovia, a settlement of 55,000 inhabitants at $10 \mathrm{~km}$ distance) and $\mathrm{NH}_{3}$ from animal husbandry (e.g. pig farms) (Ochoa-Hueso et al. 2011; Escudero et al.
Table 1 Main soil and vegetation characteristics at the experimental sites

References: (a) Díaz-Pinés (2011), (b) Díaz-Pinés et al. (2011a), (c) FernándezAlonso et al. (2018b), (d) Díaz-Pinés et al. (2011b), (e) FernándezAlonso et al. (2018a)

*Based on fungal to bacterial phospholipid fatty acid (PLFA) biomarkers in the uppermost $10 \mathrm{~cm}$ of the soil profile

\begin{tabular}{llll}
\hline Parameter & Scots pine & Pyrenean oak & Reference \\
\hline Tree biomass $\left(\mathrm{Mg} \mathrm{C} \mathrm{ha}^{-1}\right)$ & 201 & 54 & (a) \\
Net primary productivity $\left(\mathrm{Mg} \mathrm{C} \mathrm{ha}^{-1} \mathrm{a}^{-1}\right)$ & 4.8 & 1.0 & (a) \\
Aboveground litterfall $\left(\mathrm{Mg} \mathrm{C} \mathrm{ha}^{-1} \mathrm{a}^{-1}\right)$ & 2.4 & 0.9 & (b) \\
Annual soil respiration $\left(\mathrm{kg} \mathrm{CO}_{2}-\mathrm{C} \mathrm{m}^{-2} \mathrm{a}^{-1}\right)$ & 1.05 & 1.00 & (c) \\
Soil C stock $\left(\mathrm{Mg} \mathrm{ha}^{-1}\right)$ & 83.4 & 39.1 & (d) \\
Soil N stock $\left(\mathrm{Mg} \mathrm{ha}{ }^{-1}\right)$ & 5.4 & 4.2 & (d) \\
Soil bulk density $\left(\mathrm{g} \mathrm{cm}^{-3}\right)$ & 0.84 & 1.24 & (d) \\
Soil pH & 4.2 & 5.0 & (d) \\
Soil C:N ratio (0-10 cm) & 22.0 & 12.3 & (d) \\
Fungal to bacterial ratio* & 0.20 & 0.13 & (e) \\
Autotropic respiration contribution $(\%)$ & 11 & 25 & (c) \\
Heterotrophic respiration contribution $(\%)$ & 89 & 75 & (c) \\
\hline
\end{tabular}


2016). The background atmospheric $\mathrm{N}$ deposition ranges from 10 to $15 \mathrm{~kg} \mathrm{~N}_{\text {ha }}{ }^{-1} \mathrm{a}^{-1}$ (García-Gómez et al. 2014). This area has a continental Mediterranean mountain climate with a mean annual precipitation of $648 \mathrm{~mm}$ and a mean annual temperature of $10.4{ }^{\circ} \mathrm{C}$ (2014-2017). There is a strong seasonality, with the precipitation being concentrated mostly from late autumn to mid spring. The summer is warm and has a marked drought that lasts roughly from July to September. The winter is cold and a thin snow cover may be present up to several weeks, although it is highly variable between years. Soils are Humic Cambisols (IUSS Working Group WRB 2015) formed on a siliceous bedrock with sandy loam texture.

Two representative areas separated by a distance of $1400 \mathrm{~m}$ in the altitudinal ecotone were used for the experiment: one Pyrenean oak coppice and one evenaged Scots pine forest. The oak forest has a density of 932 stems $^{-1}$ of around 60-year old, resulting from an earlier use as a coppice which stopped during the early 1960s (Ximénez de Embún 1977). The Scots pine stand is managed since more than a century with a uniform shelterwood system, with 80-year old trees in a density of 718 trees ha ${ }^{-1}$ (Díaz-Pinés et al. 2011b). The proximity of selected areas minimizes variabilities in site-specific confounding factors related to parent material, soil type, macroclimate and former land use, facilitating the study of the effects of $\mathrm{N}$ fertilization on soils under Scots pine and Pyrenean oak species. Previous studies in this area highlighted vegetation-induced differences on soil $\mathrm{C}$ and $\mathrm{N}$ dynamics through different stocks, soil stoichiometry, microbial communities and relative contribution of autotrophic and heterotrophic components of $R_{S}$ to annual fluxes (Díaz-Pinés et al. 2011a, b; FernándezAlonso et al. 2018a, b). Selected relevant information of soils and vegetation for this study is gathered in Table 1 . In the pine stand, the litter layer is $1-2 \mathrm{~cm}$ thick while in the oak stand there is only a transient layer of leaves (Díaz-Pinés et al. 2011b).

\section{Experimental design}

Twenty-four plots of $2 \mathrm{~m} \times 2 \mathrm{~m}$ each were stablished in January 2014 ( 2 forest types $\times 3$ treatments $\times 4$ spatial replicates). The experimental plots were randomly assigned to the $\mathrm{N}$-fertilization treatments: control, medium and high $\mathrm{N}$ dose $(0,+10$ and $+40 \mathrm{~kg} \mathrm{~N} \mathrm{ha}^{-1} \mathrm{a}^{-1}$, respectively), with a mean separation of $26 \mathrm{~m}$ to avoid unintentional $\mathrm{N}$ contamination between plots. Considering the background atmospheric $\mathrm{N}$ deposition (García-Gómez et al. 2014), plots were receiving approximately 10-15, 20-25 and 50-55 kg N ha ${ }^{-1} \mathrm{a}^{-1}$. The high-N treatment falls out of the forecasted scenarios of $\mathrm{N}$ deposition for the Mediterranean region (up to $20 \mathrm{~kg} \mathrm{~N} \mathrm{ha}^{-1} \mathrm{a}^{-1}$ by 2030, Bobbink et al. 2010), but it was included in order to encompass a wide range of $\mathrm{N}$ deposition rates, in line with similar experiments (Lo Cascio et al. 2017; Forstner et al. 2019). We used ammonium nitrate $\left(\mathrm{NH}_{4} \mathrm{NO}_{3} 34.5 \% \mathrm{~N}\right.$, Fertiberia S.A., Puertollano, Spain) as fertilizer. Fertilization was split in equal doses applied in April, June, September and December/January. At each event, the fertilizer was evenly sprayed over the whole surface of the plots as wet deposition, equivalent to $0.5 \mathrm{~mm}$ rainfall, an amount which was insufficient to cause any detectable increase in soil water content. Untreated control plots received an equivalent application of tap water in every fertilization campaign. We mimicked wet deposition only, but we consider this is an adequate proxy for total deposition, as the method also simulates the incorporation of $\mathrm{N}$ from soil and plant surfaces into the soil (Ochoa-Hueso et al. 2011). Twelve fertilization events were conducted from June 2014 to May 2017.

\section{Soil $\mathrm{CO}_{2}$ efflux}

In January 2014, two polyvinylchloride respiratory collars ( $0.2 \mathrm{~m}$ diameter) were installed in each plot at a depth of $0.02 \mathrm{~m}$ into the mineral soil and remained in the field until the end of the experiment. To avoid potential edge effects, the collars were onset in the inner $1 \mathrm{~m} \times 1 \mathrm{~m}$ area of the plot. The respiratory collars were monthly monitored throughout the experimental period (June 2014-May 2017); additionally, during $\mathrm{N}$-fertilization events, $\mathrm{R}_{\mathrm{S}}$ measurements were conducted both before $(1 \mathrm{~h})$ and after $(24 \mathrm{~h})$ each $\mathrm{N}$ addition to address the short-term response to $\mathrm{N}$ flushes. The monitoring of $\mathrm{R}_{\mathrm{S}}$ was carried out between 7:30 and 16:30 h (local winter time) fully randomizing the sampling sequence across plots to account for potential diel fluctuations. We used a self-made chamber lid (4.04 1 volume; additional details of chamber design are provided in Fernández-Alonso et al. 2018b) which was placed onto the collar during $\mathrm{R}_{\mathrm{S}}$ measurements, acting as a non-steady-state through-flow chamber. The chamber was connected 
to a portable infrared gas analyser WMA-4 (PP Systems, Hertfordshire, United Kingdom) with air circulating with a constant rate set to $0.51 \mathrm{~min}^{-1}$. The air $\mathrm{CO}_{2}$ concentration was recorded every $30 \mathrm{~s}$ over a measurement period of $5 \mathrm{~min}$. Soil respiration rates were calculated as the linear increase of $\mathrm{CO}_{2}$ concentration in the chamber headspace over time, since no levelling off in the $\mathrm{CO}_{2}$ concentration was observed during the closure period $\left(\mathrm{R}^{2}>0.95\right.$ in all cases, mean $\left.\mathrm{R}^{2}=0.997\right)$. The first minute after chamber closure was discarded for the calculations to avoid initial fluctuations when closing the chamber. The individual plots were also monitored for soil moisture at $12 \mathrm{~cm}$ depth with a time-domain reflectometer (Field Scout TDR 100, Spectrum Technologies, Inc., Aurora, IL, USA) and surface air and soil temperatures at $10 \mathrm{~cm}$ depth with a Termistor Vertix 5989M (Herter Instruments, Barcelona, Spain). In each measurement campaign, $R_{S}$ rates were averaged at the plot level to avoid spatial correlation in the statistical data analysis $(n=2$ respiratory collars within each plot). We computed averaged rates of $\mathrm{R}_{\mathrm{S}}$ for every month of the year and expressed them as $\mathrm{Mg} \mathrm{CO}$-C ha ${ }^{-1}$ month $^{-1}$ for a convenient display. We calculated cumulative $\mathrm{R}_{\mathrm{S}}$ rates for the whole study period $\left(\mathrm{Mg} \mathrm{CO}_{2}-\mathrm{C} \mathrm{ha}{ }^{-1}\right)$ using linear interpolation between consecutive measurement campaigns.

Soil sampling and laboratory analyses

Three soil sampling campaigns were performed in the spring of 2015, 2016 and 2017, $24 \mathrm{~h}$ after the application of $\mathrm{N}$-fertilizer to address the short-term responses of selected soil parameters. We used a $1 \mathrm{~m} \times 1 \mathrm{~m}$ sampling area centred in each plot and divided into a regular grid $(0.1 \mathrm{~m} \times 0.1 \mathrm{~m})$. The locations of the respiratory collars were avoided. In each sampling day, any litter was removed and three cores of mineral soil ( $0.1 \mathrm{~m}$ depth, $0.05 \mathrm{~m}$ diameter) were taken in randomly selected spots. The empty holes were filled with inert gravel material. Samples were taken out of the corers undisturbed and split into two depths $(0-5 \mathrm{~cm}$ and $5-10 \mathrm{~cm})$ and further pooled in a composite sample per plot and depth increment. Samples were delivered in ice to the lab, sieved (mesh size $<2 \mathrm{~mm}$ ) and stored at $4{ }^{\circ} \mathrm{C}$ until soil extractions for microbial biomass, ammonium $\left(\mathrm{NH}_{4}{ }^{+}\right)$and nitrate $\left(\mathrm{NO}_{3}{ }^{-}\right)$determinations were performed. Then, soil extracts were stored at $-20{ }^{\circ} \mathrm{C}$ until analysis. Air- dried soil samples were used for the rest of the analysis.

Soils were extracted with $0.5 \mathrm{M} \mathrm{K}_{2} \mathrm{SO}_{4}$ (1:5, w:v) and the extracts were analysed using the salicylate method for $\mathrm{NH}_{4}{ }^{+}$concentration and the vanadium(III) chloride method for $\mathrm{NO}_{3}{ }^{-}$concentration. Microbial biomass $\mathrm{C}$ and $\mathrm{N}$ were calculated as the difference in $\mathrm{K}_{2} \mathrm{SO}_{4}$-extractable organic $\mathrm{C}$ (EOC) and $\mathrm{N}$ between chloroform-fumigated samples and control samples, respectively (Vance et al. 1987). Soil pH was determined with a calibrated pH-meter (micropH-2000, Crison Instruments SA, Barcelona, Spain) in $1 \mathrm{M} \mathrm{KCl}$ (soil:suspension ratio of 1:2.5, w:v). Potassium $\left(\mathrm{K}^{+}\right)$ was determined on soil extracts $(1: 10, \mathrm{w}: \mathrm{v})$ with $1 \mathrm{~N}$ ammonium acetate using a flame photometer (PFP-7, Jenway, Stone, United Kingdom). Soil phosphate $\left(\mathrm{PO}_{4}{ }^{3-}\right)$ concentration was measured with a spectrophotometer (Evolution 201, Thermo Scientific, Waltham, MA, USA) following the modified ascorbic acid method. Soil organic C and total nitrogen (TN) were determined in soil samples using an elemental analyser (CNS 2000, LECO Corporation, St. Joseph, MI, USA). Total soil $\mathrm{C}$ equals soil organic $\mathrm{C}$ because soils investigated here are developed over siliceous bedrock and carbonate-free. Roots were picked up by hand from the soil samples during sieving and total root biomass (fine + coarse roots) weight was determined after oven drying for $48 \mathrm{~h}$ at $50{ }^{\circ} \mathrm{C}$. These estimates represent only a fraction of the total root biomass because of the shallowed depth sampled $(0-10 \mathrm{~cm})$. Soil water contents of field-moist and airdried soil samples were determined gravimetrically by oven-drying soil aliquots at $105^{\circ} \mathrm{C}$ to constant mass. Soil $\mathrm{C}$ and $\mathrm{N}$ stocks at both sampling depths were calculated following IPCC guidelines and using SOC and TN concentrations estimated here, and mean values of soil bulk density, fine earth and stone content of each forest estimated by Díaz-Pinés et al. (2011b) for the same experimental forest stands (Table 1).

We used the metabolic quotient $\left(\mathrm{qCO}_{2}\right)$ as proxy of the $\mathrm{C}$ use efficiency of soil microbial communities (Creamer et al. 2015). We calculated the $\mathrm{qCO}_{2}(\mathrm{mg}$ $\mathrm{CO}_{2}-\mathrm{C} \mathrm{g}^{-1}$ microbial $\mathrm{C} \mathrm{h}^{-1}$ ) as the ratio between heterotrophic soil respiration $\left(\mathrm{mg} \mathrm{CO}_{2}-\mathrm{C} \mathrm{m}^{-2} \mathrm{~h}^{-1}\right)$ and microbial biomass ( $\mathrm{g}$ microbial $\mathrm{C} \mathrm{m}^{-2}$ ); thus, a higher $\mathrm{qCO}_{2}$ denotes a lower microbial $\mathrm{C}$ use efficiency. The microbial respiration was estimated according to the relative contribution of the heterotrophic fraction to $\mathrm{R}_{\mathrm{S}}$ (Table 1) in each forest 
(Fernández-Alonso et al. 2018b). Microbial biomass estimated in ( $\mathrm{g}$ microbial $\mathrm{C} \mathrm{g}^{-1}$ soil $\mathrm{dw}$ ) was converted to (g microbial $\mathrm{C} \mathrm{m}^{-2}$ ) based on sampling depths and soil bulk density (Table 1) in each forest (Díaz-Pinés et al. 2011b), and then aggregated at plot level. The $\mathrm{qCO}_{2}$ may allow for direct comparison of microbial carbon use efficiency between different treatments but requires the assumption of negligible changes in the relative contribution of the autotrophic and the heterotrophic respiration components to $\mathrm{R}_{\mathrm{S}}$ due to $\mathrm{N}$ addition.

\section{Data analysis}

The Kruskal-Wallis test was used to compare soil temperature and water content between forests. We evaluated the effects of 3 years of $\mathrm{N}$ fertilization on soil biological and chemical properties in Scots pine and Pyrenean oak forests using separated linear mixed-effects (LME) models for each sampling depth. The LME models included the interaction effect between 'Forest' and 'Treatment', and also the random intercept 'Plot' given that data consisted of repeated measures (lme4 package, Bates et al. 2015). Further, a generalized linear model (GLM) with gamma error distribution and the logarithmic link function was conducted to test the interaction effect between 'Forest' and 'Treatment' on $\mathrm{qCO}_{2}$ including the random intercept 'Plot'. Since the seasonal evolution of $\mathrm{R}_{\mathrm{S}}$ may obscure the effect of $\mathrm{N}$-fertilization treatments, we used separated LME models with the random intercept 'Plot' to evaluate differences in monthly values of $R_{S}$ between treatments within each forest, and between forests within the same treatment. We compared $\mathrm{R}_{\mathrm{S}}$ before and $24 \mathrm{~h}$ after the $\mathrm{N}$-fertilization event using the Kruskal-Wallis test separately for each fertilization treatment and forest. Additionally, we used a linear model to test the interaction effect between 'Forest' and 'Treatment' on the cumulative $R_{S}$ throughout the whole study period (stats package, R Core Team 2019). We inspected the general assumptions of normality and homoscedasticity in the models by plotting the residual values versus predicted values and the quantile-quantile residual plots for each fitted model. Pairwise comparisons using Tukey's honestly significant differences of leastsquare means (lsmeans package, Lenth 2016) were performed whenever significant factor effects were detected. We calculated the marginal and conditional
$\mathrm{R}^{2}$ as a goodness-of-fit measure for GLM and LME models (MuMIn package, Barton 2018).

Structural equation modelling (SEM) was used to evaluate the direct and indirect influence of selected soil properties on $\mathrm{R}_{\mathrm{S}}$ and to determine how short-term $\mathrm{N}$ flushes may affect these causal relationships. SEM is a multivariate statistical method that compares the observed covariances among measured variables to those expected based on an aprioristic model in which causal networks are explicitly depicted (Iriondo et al. 2003). The hypothesized relationships among variables (Fig. S1) were based on literature and previous statistical analysis (LME models). First, we hypothesized that $R_{S}$ would depend on soil temperature and soil water content (Almagro et al. 2009), and that both predictor variables would be correlated (FernándezAlonso et al. 2018b). Second, we anticipated that $R_{S}$ would be influenced by abiotic and biotic conditions in soils, namely pH (Xu and Qi 2001; Rousk et al. 2010), EOC (Søe and Buchmann 2005), inorganic N concentrations (Sun et al. 2014), microbial biomass (Liu and Greaver 2010), and that all these variables would be affected by SOC stocks (de Vries et al. 2012) and fertilization treatments (Treseder 2008; Janssens et al. 2010; Riggs and Hobbie 2016). The N-fertilization treatment was encoded as an ordinal variable. To test the model, we supplemented the dataset of the analysed soil properties for the top $5 \mathrm{~cm}$ with the measurements of $R_{S}$ developed $24 \mathrm{~h}$ after each $\mathrm{N}$-fertilizer spreading. Separated SEM were run for the dataset of each forest type, containing all variables z-standardized. Model estimations were performed using maximum likelihood methodology, and the adequacy of the fit was evaluated by $\chi^{2}$ goodness of fit and other statistics often used in SEM (Browne and Cudeck 1993; Shipley 2004), such as the Bentler and Bonnett's normed fit index (NFI), the goodness of fit index (GFI) and the root mean square error approximation (RMSE). We tested for both univariate and multivariate normality and evaluated the statistical significance of each regression weight through bootstrapping (Finney and DiStefano 2006). Before assessing the models, we checked for multi-collinearity patterns in our dataset calculating the variance inflation factor of each predictor variable and using a threshold level of four. Furthermore, we explored if there were differences in the influence of $\mathrm{N}$ fertilization on $R_{S}$ between forests through the explicit comparisons performed with a multi-group analysis 
(Shipley 2004). We applied the Bonferroni correction to adjust the overall significance level to the number of cases tested in these multi-group comparisons.

Statistical analyses were carried out in the statistical platform $\mathrm{R}$ version 3.4.0. (R Core Team 2019) except for the fit and evaluation of SEMs and the multi-group analyses, which were performed with the Amos 22.0.0 software (SPSS, IBM Corporation, Meadville, PA, USA). Significance level was established in all tests at $\mathrm{p}<0.05$, unless otherwise stated.

\section{Results}

Soil properties as affected by vegetation type

There were no statistical differences in soil microclimate between forests (Kruskal-Wallis, $\mathrm{df}=1$; soil water content, $\chi^{2}=0.930$; soil temperature, $\left.\chi^{2}=0.922\right)$. Mean soil temperature was $12.2 \pm 0.6{ }^{\circ} \mathrm{C}$ (ranging from $1.4{ }^{\circ} \mathrm{C}$ in winter to $23.8{ }^{\circ} \mathrm{C}$ in summer) and mean soil moisture was $8.2 \pm 1.4 \%$ vol. (ranging from $<1 \%$ in summer to $21.3 \%$ in late winter). During winter and late-autumn, oak stands tended to have higher soil moisture levels (Fig. 1), although this trend was not statistically significant.

The soil microbial $\mathrm{C}$ and $\mathrm{N}$ was lower in pine stands than in oak ones $(12.1 \pm 5.6$ and $21.5 \pm 4.8 \mathrm{mg} \mathrm{C}$ $\mathrm{g}^{-1}$ SOC; $33.3 \pm 14.8$ and $48.1 \pm 14.9 \mathrm{mg} \mathrm{N} \mathrm{g}^{-1}$ $\mathrm{TN}$; respectively in the top $10 \mathrm{~cm}$; layer-wise results in Table S1). The soil microbial C:N ratio was lower under oak than under pine $(6.2 \pm 1.4$ and $7.9 \pm 1.6$, respectively in the top $10 \mathrm{~cm}$ ). The SOC stock in the uppermost $10 \mathrm{~cm}$ was significantly higher in the pine than in the oak forest $(42.7 \pm 13.4$ and $35.1 \pm 5.4 \mathrm{Mg} \quad \mathrm{C} \mathrm{ha}^{-1}$, respectively; layer-wise results in Table S2), while the contrary was observed for the soil $\mathrm{N}$ stocks $(2.0 \pm 0.6$ and $2.6 \pm 0.4 \mathrm{Mg} \mathrm{N}^{-1}$ in pine and oak stands, respectively). Soil $\mathrm{C}: \mathrm{N}$ ratio in the pine forest was nearly twofold the one in the oak forest $(21.8 \pm 2.4$ and $13.2 \pm 0.9$, respectively).

Ammonium was the dominant inorganic- $\mathrm{N}$ form in the soils, regardless of tree species (Table S2). In control plots the $\mathrm{NO}_{3}{ }^{-}-\mathrm{N}: \mathrm{NH}_{4}{ }^{+}-\mathrm{N}$ ratio was on average $0.14 \pm 0.09$ and $0.23 \pm 0.19$ in pine and oak forests, respectively. Soil $\mathrm{NH}_{4}{ }^{+}$and $\mathrm{NO}_{3}{ }^{-}$ concentrations in the uppermost $5 \mathrm{~cm}$ of the soil were higher in oak than in pine forests (Fig. 2c; Table S2). Soil $\mathrm{pH}$ was slightly more acidic in the pine than in the oak forest (Fig. 2d). The $\mathrm{K}^{+}$concentrations were higher in oak than in pine stands (Fig. 2e). Extractable $\mathrm{PO}_{4}{ }^{3-}$ was low $\left(3.8 \pm 1.4 \mathrm{mg} \mathrm{P} \mathrm{kg}{ }^{-1}\right.$ $\mathrm{dw})$ and rather similar between forests in the top layer (Table S2). The $\mathrm{qCO}_{2}$ was significantly higher in Scots pine than in Pyrenean oak forests (Fig. 3; Table S3).

Short-term effects of $\mathrm{N}$ additions on soil properties

In the short term, soil microbial biomass $\mathrm{C}$ decreased after $\mathrm{N}$ addition in both tree species and in the two soil depths analysed (Figs. 2a, S2a), while microbial biomass $\mathrm{N}$ remained unaffected (Table $\mathrm{S} 1$ ). The soil microbial C: $\mathrm{N}$ ratio was not influenced by $\mathrm{N}$ fertilization in any of the studied soil layers, despite a nonsignificant reduction in the uppermost $5 \mathrm{~cm}$ of the soil under pine of 1.3-1.5 units (Table S1). In the first $5 \mathrm{~cm}$ of the soil under pine, the EOC decreased with $\mathrm{N}$ addition whereas it remained stable in the soil under oak (Fig. 2b). Nitrate concentrations showed a significant increase in fertilized plots, with a larger response in the first $5 \mathrm{~cm}$ of the soil profile (Figs. 2c, S2c). Soil $\mathrm{pH}$ values showed a small but significant reduction with the high-N fertilization in both forests (Fig. 2d). In both forests, $\mathrm{K}^{+}$concentrations were higher under medium-fertilization compared to high-fertilization, whereas control plots showed intermediate values (Fig. 2e). In both forests, the medium-fertilization treatment showed increased $\mathrm{qCO}_{2}$ values compared to the control treatment (Fig. 3; Table S3).

\section{Soil respiration}

Soil respiration followed the same temporal pattern in both oak and pine forests (Fig. 1; Table 2): $\mathrm{R}_{\mathrm{S}}$ peaked in March-July and in October, corresponding to the periods with high values of both soil temperature and soil moisture (Fig. 1). For the period from May to August (the period with the warmest soil temperature) $\mathrm{R}_{\mathrm{S}}$ was higher in the oak than in the pine forest. The medium-fertilization significantly increased $R_{S}$ in the Scots pine stand from February to May and in September, whereas the high-fertilization only showed significant increases in February. In the oak forest, medium-fertilization significantly increased $R_{S}$ only in April with high-fertilization showing intermediate values between control and medium- 

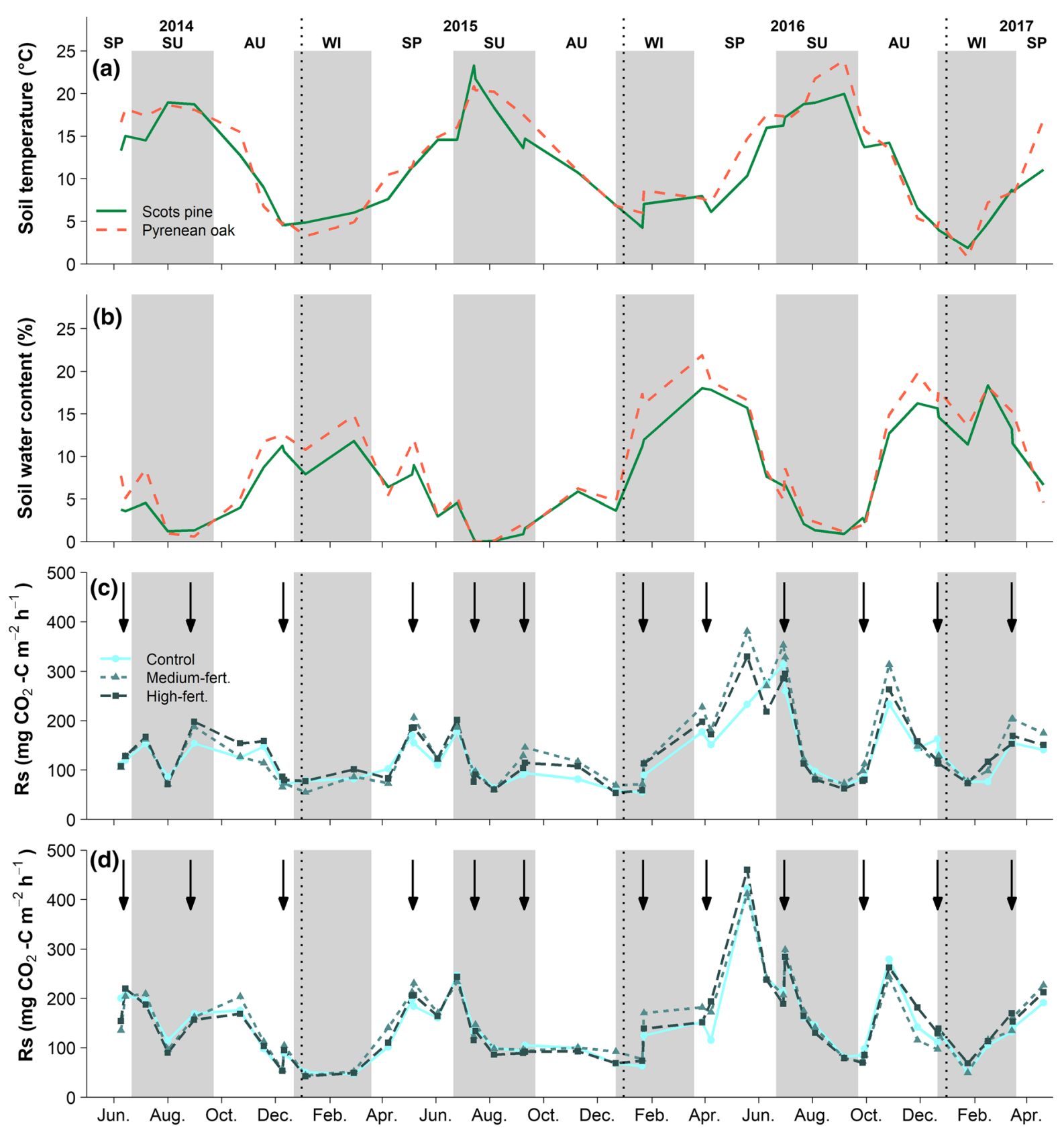

Fig. 1 Soil microclimate parameters and soil respiration $\left(R_{S}\right)$ rates over the study period (June 2014-May 2017). Average values of a soil temperature and $\mathbf{b}$ soil water content in the experimental plots $(n=12)$ from Scots pine and Pyrenean oak forests. Mean $R_{S}$ measured in $\mathbf{c}$ the Scots pine forest and $\mathbf{d}$ the

fertilization. The fertilization effect on cumulative $R_{S}$ throughout the study period (2014-2017) was not statistically significant in any of the forests (Fig. 4;
Pyrenean oak forest from control, medium- and high-fertilization plots $(n=4)$. Standard errors are omitted to improve the clarity of the figure. Arrows indicate days of application of nitrogen fertilization. Grey and white panels indicate the seasons: $S P$ spring, $S U$ summer, $A U$ autumn and $W I$ winter

Table S4). In the oak stand, $\mathrm{R}_{\mathrm{S}}$ rates increased $24 \mathrm{~h}$ after fertilizer spreading (Fig. 5), but the same trend was found in the control in which only water was 

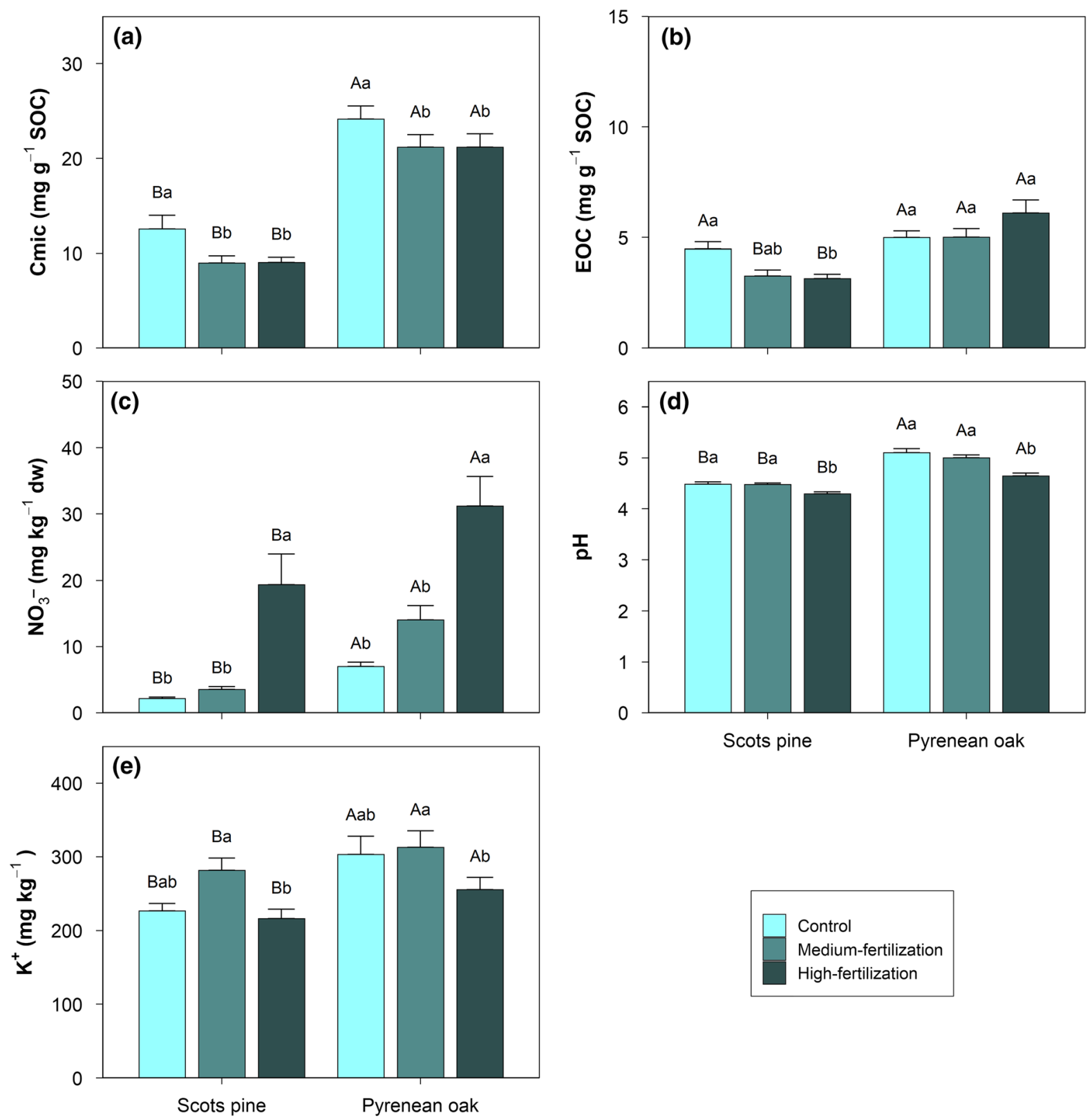

Fig. 2 Selected soil properties separated by tree species and $\mathrm{N}$-fertilization treatment at $0-5 \mathrm{~cm}$ depth (mean \pm 1 standard error). Cmic microbial biomass carbon, EOC extractable organic carbon, $\mathrm{NO}_{3}{ }^{-}$nitrate concentration, $\mathrm{K}$ potassium concentration. Different capital letters denote significant differences between

applied ( $p<0.1$, Fig. 5b). In the pine forest, no significant short-term response of $\mathrm{R}_{\mathrm{S}}$ to the application of fertilizers was found (Fig. 5).

tree species within the same $\mathrm{N}$-fertilization treatment (control, medium- and high-fertilization), while different small letters indicate significant differences between $\mathrm{N}$-fertilization treatments within the same tree species (linear mixed-effects models, $\mathrm{n}=12$ )

Direct and indirect effects of soil properties on soil respiration

The datasets collected in each forest provided a good fit to the initial hypothesized model as indicated by the non-significant $\chi^{2}$ values and the goodness of fit 


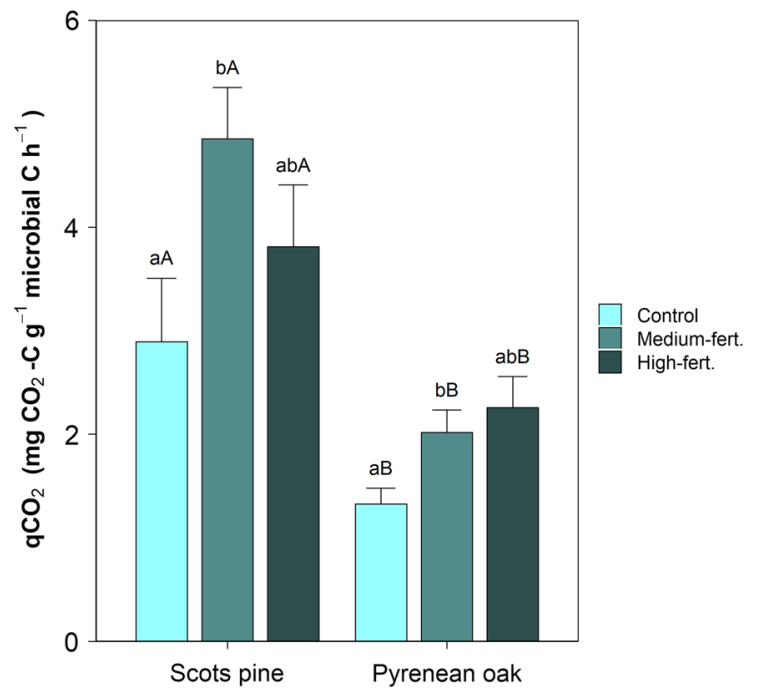

Fig. 3 Microbial metabolic quotient $\left(\mathrm{qCO}_{2}\right)$ according to tree species and $\mathrm{N}$-fertilization treatments (mean \pm 1 standard error). Different capital letters denote significant differences between tree species, while different small letters indicate significant differences between $\mathrm{N}$-fertilization treatments (generalized linear mixed model, $\mathrm{n}=12$ )

indices (RMSE < 0.05, NFI and GFI > 0.9; Browne and Cudeck 1993, Fig. 6a, b). The SEMs were able to explain the $51 \%$ and $58 \%$ of the variation in $\mathrm{R}_{\mathrm{S}}$ in the Scots pine and the Pyrenean oak forests, respectively. The predictor variables soil moisture and soil temperature that were similar in both forests during the measurement campaigns, explained the greatest amount of variability in $R_{S}$ and had stronger standardized effects in the Pyrenean oak forest than in the Scots pine forest (Fig. 6c; Table S6). The SEMs revealed a strong effect of $\mathrm{N}$ fertilization on soil $\mathrm{NO}_{3}{ }^{-}$ concentrations, but not on soil $\mathrm{NH}_{4}{ }^{+}$concentrations (Fig. 6a, b; Table S5). Soil $\mathrm{NH}_{4}^{+}$concentrations negatively influenced $\mathrm{R}_{\mathrm{S}}$ in both forest types; whereas soil $\mathrm{NO}_{3}{ }^{-}$concentrations stimulated $\mathrm{R}_{\mathrm{S}}$ in the pine forest, only (Fig. 6c). The direct effect of $\mathrm{N}$ additions on soil $\mathrm{pH}$ was only significant in the oak forest, although in both forests $\mathrm{N}$ fertilization indirectly reduced soil $\mathrm{pH}$ through the modulation of $\mathrm{NO}_{3}{ }^{-}$ (Fig. 6a, b; Table S5). Soil pH in turn exerted a total negative effect on $\mathrm{R}_{\mathrm{S}}$ (Fig. 6c). Fertilization acidified the soil, which resulted in higher $\mathrm{R}_{\mathrm{S}}$ rates in both forests. Microbial biomass $C$ did not influence $R_{S}$ in any of the tree species (Fig. 6c), albeit its strong reduction after $\mathrm{N}$ additions (Fig. 6a, b). Further, the paths from $\mathrm{N}$ fertilization to EOC and from EOC to $\mathrm{R}_{\mathrm{S}}$ differed in direction, statistical significance and magnitude between forests (Table S6). The EOC increased with soil acidification in both tree species (Fig. 6a, b), with negative effects for $R_{S}$ in pine and positive in oak (Fig. 6c). In soils under pine, the reduction in microbial biomass $\mathrm{C}$ with $\mathrm{N}$ fertilization caused a modest increase in EOC (Fig. 6a; Table S5). The EOC experienced a strong decrease with $\mathrm{N}$ additions in the pine stand (Fig. 6a; Table S5). The interconnections between the inorganic $\mathrm{N}$ forms and pools of $\mathrm{C}$ (Stock $\mathrm{C}$ and EOC) were different between forests (Table S6). The total effect of fertilization on $R_{S}$ was positive and significant only in the case of the pine stand (Fig. 6c).

\section{Discussion}

Soil respiration response to enhanced $\mathrm{N}$ deposition rates

We hypothesised reductions of $R_{S}$ rates for both tree species in response to $\mathrm{N}$ enrichment since it is the generally observed trend in temperate forests in manipulative experiments (Janssens et al. 2010; Zhou et al. 2014; Zhong et al. 2016). This has to be rejected since we observed largely no response (or even transient increases) in the $R_{S}$ rates in the fertilized treatments (Table 1; Fig. 4). We suggest that the marked seasonality of the Mediterranean climate, which strongly constrains soil biological activity, is mostly responsible for the observed stability (Fig. 1). Even if the availability of soil $\mathrm{N}$ increases, water scarcity and/or low temperatures may still limit plant nutrient uptake (Sardans et al. 2011) or soil microbial transformations, and thereby $\mathrm{R}_{\mathrm{S}}$ (Almagro et al. 2009; Fernández-Alonso et al. 2018b). Following this argument, the seasonality of precipitations influences not only the $\mathrm{R}_{\mathrm{S}}$ rates per se, but also its response to $\mathrm{N}$ addition, which is suppressed during the dry period (Zhang et al. 2014; Lo Cascio et al. 2017). Likewise, the soil activity was limited in winter due to the low temperatures and the apparently higher soil moisture values observed in the oak stand after leaves senescence did not trigger a differential response upon rewetting (Figs. 1, 5). Thus, we propose a hierarchy in environmental limitations, in which the climate constraints of the Mediterranean regions play a predominant role in limiting the $\mathrm{R}_{\mathrm{S}}$ response to the addition of 
Table 2 Monthly averaged soil respiration $\left(\mathrm{Mg} \mathrm{CO}_{2}-\mathrm{C}\right.$ $\mathrm{ha}^{-1}$ month $^{-1}$ )

Values are

means \pm standard deviations with $\mathrm{n}=$ number of sampling events for each month. For each month, different capital letters denote significant differences between forests within the same treatment (control, medium- or highfertilization), while different small letters indicate significant differences between treatments within the same forest (linear mixed-effects models; p-value $<0.1$ )

\begin{tabular}{|c|c|c|c|c|c|c|c|c|c|c|}
\hline \multirow[t]{2}{*}{ Month } & \multirow[t]{2}{*}{$\mathrm{n}$} & \multicolumn{9}{|l|}{ Scots pine } \\
\hline & & \multicolumn{3}{|l|}{ Control } & \multicolumn{3}{|l|}{ Medium-fert } & \multicolumn{3}{|l|}{ High-fert } \\
\hline Jan & 4 & $0.6 \pm 0.2$ & & & $0.6 \pm 0.2$ & & & $0.6 \pm 0.2$ & & \\
\hline Feb & 2 & $0.5 \pm 0.1$ & $\mathrm{~b}$ & & $0.6 \pm 0.1$ & $\mathrm{ab}$ & & $0.7 \pm 0.2$ & a & \\
\hline Mar & 3 & $1.2 \pm 0.3$ & $\mathrm{~b}$ & & $1.6 \pm 0.3$ & a & A & $1.3 \pm 0.4$ & $a b$ & \\
\hline Apr & 3 & $0.8 \pm 0.2$ & $\mathrm{~b}$ & & $1.2 \pm 0.4$ & a & & $1.0 \pm 0.4$ & $a b$ & \\
\hline May & 3 & $1.4 \pm 0.4$ & $\mathrm{~b}$ & B & $1.9 \pm 0.9$ & $\mathrm{a}$ & & $1.7 \pm 0.7$ & $a b$ & \\
\hline Jun & 6 & $1.3 \pm 0.7$ & & B & $1.5 \pm 0.8$ & & & $1.3 \pm 0.6$ & & B \\
\hline Jul & 5 & $1.1 \pm 0.6$ & & B & $1.2 \pm 0.8$ & & B & $1.1 \pm 0.6$ & & B \\
\hline Ago & 4 & $0.7 \pm 0.3$ & & B & $0.7 \pm 0.4$ & & B & $0.7 \pm 0.4$ & & B \\
\hline Sept & 5 & $0.6 \pm 0.1$ & $\mathrm{~b}$ & & $0.8 \pm 0.3$ & a & & $0.6 \pm 0.2$ & $\mathrm{~b}$ & \\
\hline Oct & 2 & $1.3 \pm 0.5$ & & & $1.6 \pm 0.8$ & & & $1.6 \pm 0.5$ & & \\
\hline Nov & 3 & $0.9 \pm 0.3$ & & & $0.9 \pm 0.2$ & & & $1.0 \pm 0.2$ & & \\
\hline Dec & 5 & $0.8 \pm 0.4$ & & & $0.7 \pm 0.2$ & & & $0.7 \pm 0.2$ & & \\
\hline \multirow[t]{2}{*}{ Month } & \multirow[t]{2}{*}{$\mathrm{n}$} & \multicolumn{9}{|c|}{ Pyrenean oak } \\
\hline & & Control & & & Medium-fer & & & High-fert & & \\
\hline Jan & 4 & $0.5 \pm 0.3$ & & & $0.6 \pm 0.4$ & & & $0.6 \pm 0.3$ & & \\
\hline Feb & 2 & $0.5 \pm 0.2$ & & & $0.6 \pm 0.3$ & & & $0.6 \pm 0.3$ & & \\
\hline Mar & 3 & $1.0 \pm 0.2$ & & & $1.2 \pm 0.3$ & & B & $1.2 \pm 0.2$ & & \\
\hline Apr & 3 & $1.0 \pm 0.3$ & $\mathrm{~b}$ & & $1.3 \pm 0.5$ & $\mathrm{a}$ & & $1.2 \pm 0.4$ & $\mathrm{ab}$ & \\
\hline May & 3 & $2.0 \pm 1.0$ & & A & $2.1 \pm 0.8$ & & & $2.2 \pm 1.1$ & & \\
\hline Jun & 6 & $1.5 \pm 0.3$ & & A & $1.5 \pm 0.3$ & & & $1.5 \pm 0.3$ & & A \\
\hline Jul & 5 & $1.4 \pm 0.5$ & & A & $1.4 \pm 0.5$ & & A & $1.3 \pm 0.5$ & & A \\
\hline Ago & 4 & $1.0 \pm 0.3$ & & A & $0.9 \pm 0.2$ & & A & $0.9 \pm 0.3$ & & A \\
\hline Sept & 5 & $0.7 \pm 0.2$ & & & $0.6 \pm 0.1$ & & & $0.6 \pm 0.1$ & & \\
\hline Oct & 2 & $1.7 \pm 0.5$ & & & $1.7 \pm 0.4$ & & & $1.6 \pm 0.4$ & & \\
\hline Nov & 3 & $0.8 \pm 0.2$ & & & $0.8 \pm 0.2$ & & & $0.9 \pm 0.3$ & & \\
\hline Dec & 5 & $0.7 \pm 0.2$ & & & $0.7 \pm 0.3$ & & & $0.7 \pm 0.3$ & & \\
\hline
\end{tabular}

$\mathrm{N}$ and, when appropriate microclimatic conditions occur, the soil $\mathrm{N}$ status becomes more relevant.

In forest ecosystems, the response of $\mathrm{R}_{\mathrm{S}}$ is likely related to the a priori soil $\mathrm{N}$ status (Zhu et al. 2016). While the general trend is a decrease in the $R_{S}$ following fertilization, Janssens et al. (2010) speculated that the few observed positive $\mathrm{R}_{\mathrm{S}}$ responses were provoked by the alleviation of microbial $\mathrm{N}$ limitation. In our case, $R_{S}$ in pine stands showed a positive reaction upon medium-fertilization from February to May and then in September, while the response in oak stands was only detectable in April. In line with the current study, partner works in the area have shown large differences in the soils under each tree species (Table 1). Soils under pine have markedly higher C:N ratios (Díaz-Pinés et al. 2011b), lower inorganic N contents (Table S2), and also higher biogeochemical recalcitrance of soil organic matter compared to oak soils in the ecotone (Díaz-Pinés et al. 2011b). Further, the tree species composition shapes the structure of the microbial functional groups in soils, being the saprophytic fungi more abundant in the pine stand and the gram-negative bacteria in the oak stand (Díaz-Pinés et al. 2014; Fernández-Alonso et al. 2018a), and resulting in higher soil microbial $\mathrm{C}: \mathrm{N}$ ratio under pine than under oak (Table S2). Overall, previous and current results suggest a N-poor environment under pine, with predominantly oligotrophic microorganisms, whereas more copiotrophic microbes dominate under oak (Fernández-Alonso et al. 2018a). Thus, the 


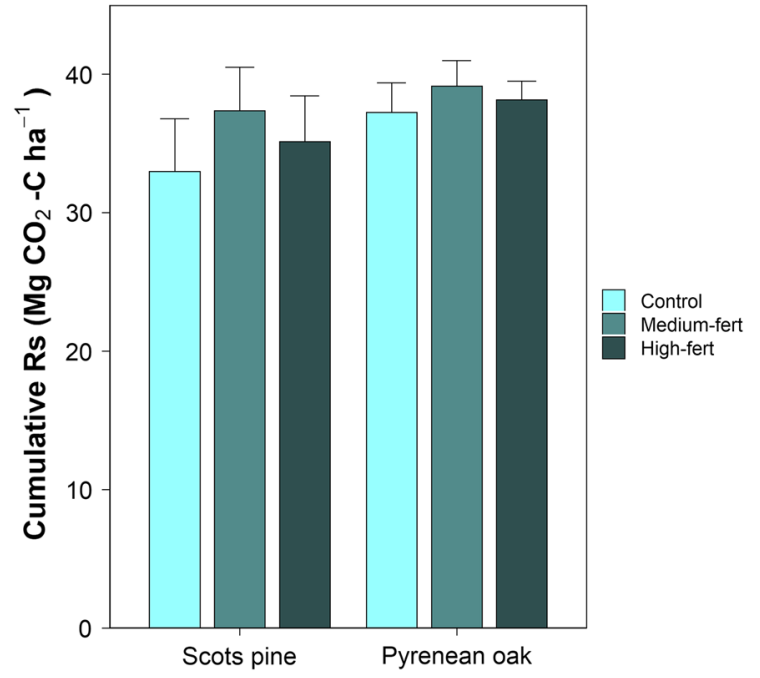

Fig. 4 Cumulative soil respiration rates (mean \pm 1 standard error) from June 2014 to May 2017 (36 months) for each tree species and treatment $(\mathrm{p}>0.05, \mathrm{n}=4)$ stronger $\mathrm{N}$ limitation in pine stands results in a higher response upon fertilization than in the oak ones, in line with studies reporting how, after $\mathrm{N}$ addition, the native $\mathrm{N}$ availability-derived from soil stoichiometryinhibits $R_{S}$ in $N$ richer sites and enhances $R_{S}$ in $N$ poorer ecosystems (Pregitzer et al. 2008; Zhu et al. 2016; Lo Cascio et al. 2017).

We investigated bulk $R_{S}$ rates and therefore we cannot discriminate whether $\mathrm{N}$ addition affected the root or the microbial respiration component, or both. Positive effects of $\mathrm{N}$ additions on $\mathrm{R}_{\mathrm{S}}$ might have been produced through a plant-mediated response by which alleviation of $\mathrm{N}$ limitation enhances the photosynthetic rates, inducing a positive loop in the forest $\mathrm{C}$ cycle by enhancing rhizosphere respiration ( $\mathrm{Lu}$ et al. 2011). Further, changes in quantity and quality of the litterfall can subsequently affect its decomposition dynamics (Knorr et al. 2005). However, given the
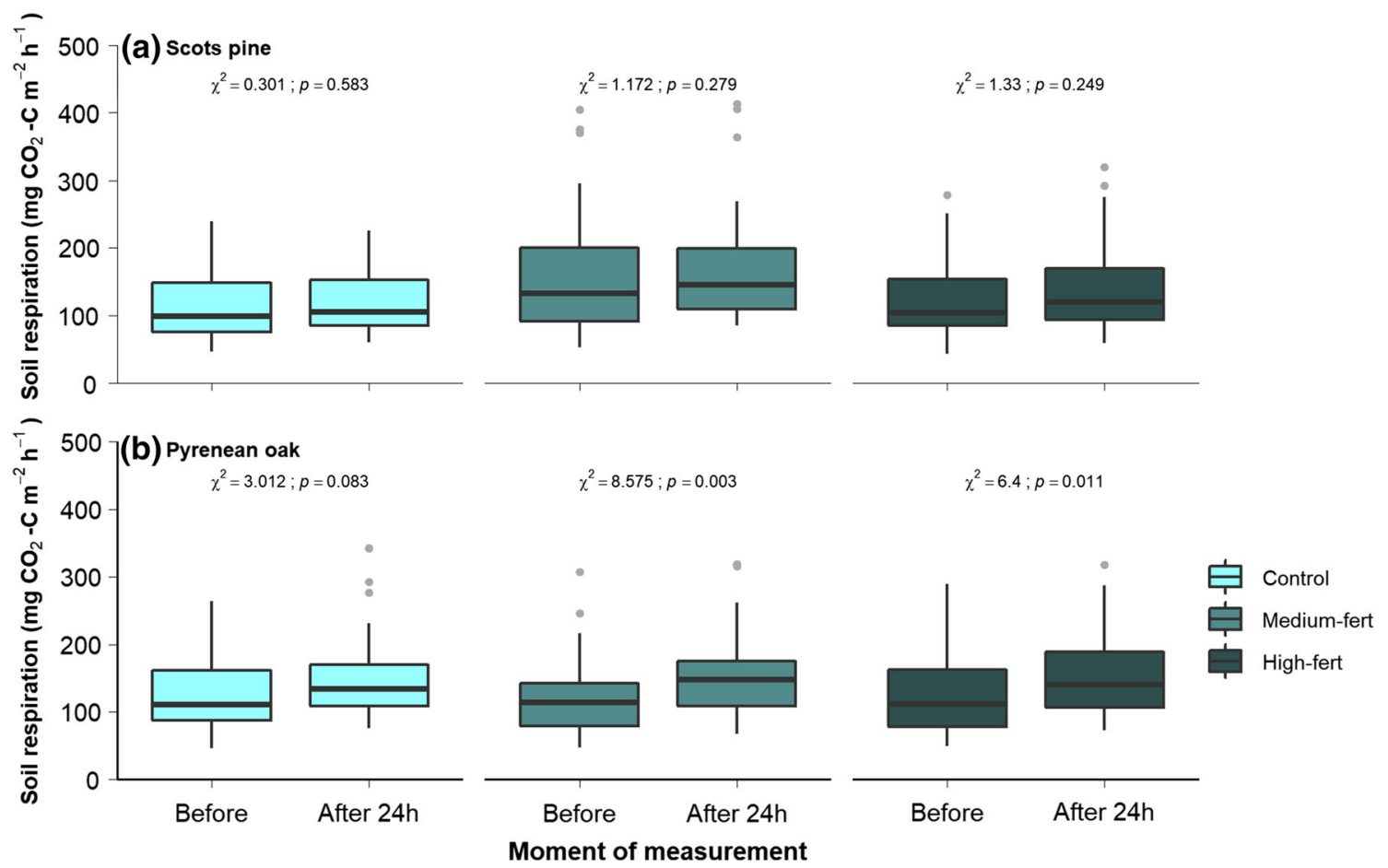

Fig. 5 Box-plot of the soil respiration rates before and $24 \mathrm{~h}$ after nitrogen fertilizer spreading in $\mathbf{a}$ Scots pine and $\mathbf{b}$ Pyrenean oak. The horizontal line represents the median value $(n=48)$; the box represents the interquartile range (IQR, 25th-75th percentile range); the lower (higher) whisker shows the smallest (greatest) observation greater than (less than) or equal to the 25th percentile minus (plus) 1.5 times the IQR. Circles represent observations falling out the median $\pm 1.5 \times \mathrm{IQR}$ range. For each tree species and $\mathrm{N}$-fertilization treatment, the $\chi^{2}$ and p-values of the Kruskal-Wallis test of "moment of measurement" are presented 

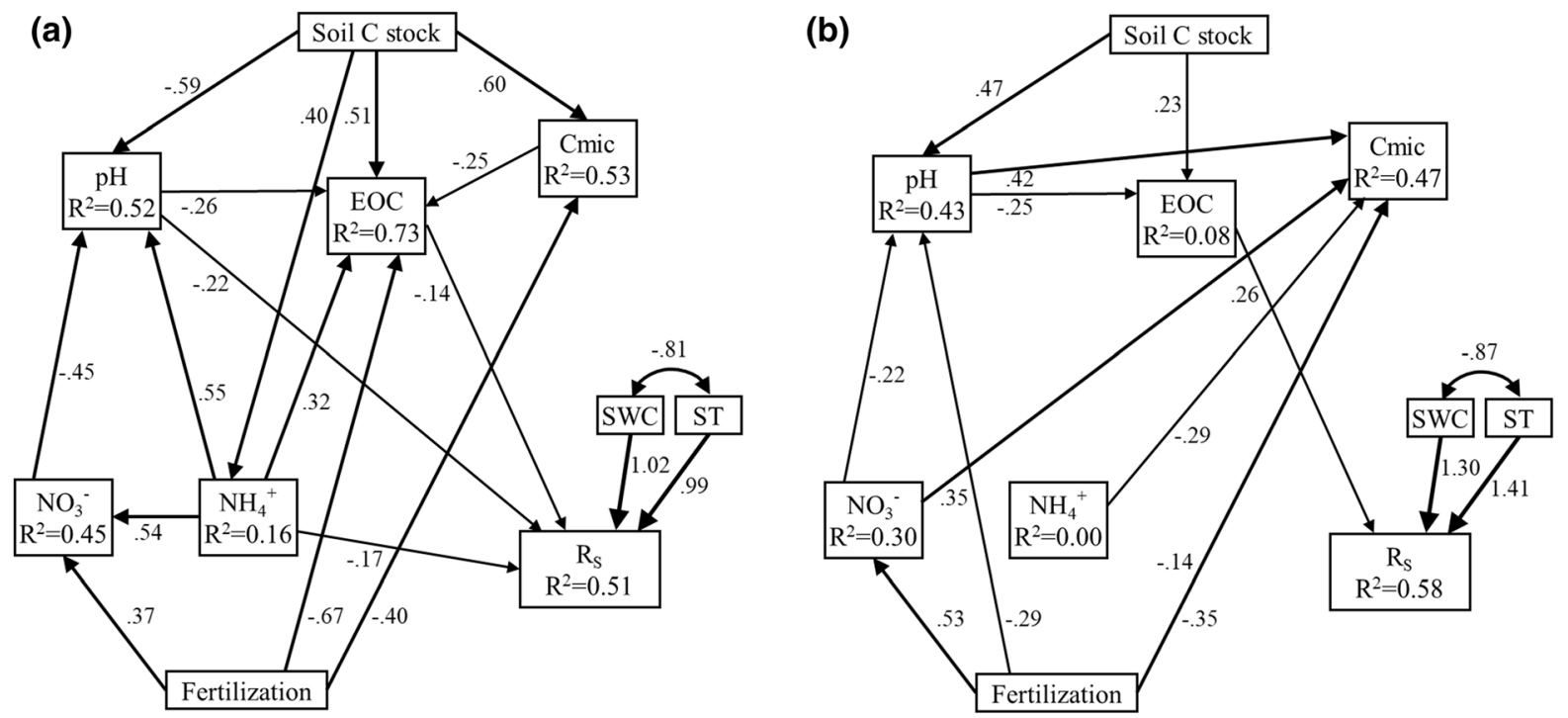

$\mathrm{NFI}=0.98 ; \mathrm{GFI}=0.98 ; \mathrm{RMSEA}=<0.001$
$\chi^{2}=17.10, \mathrm{p}=0.52 ; \mathrm{df}=18 ; \mathrm{n}=144$

$\mathrm{NFI}=0.97 ; \mathrm{GFI}=0.98 ; \mathrm{RMSEA}=<0.001$
$\chi^{2}=15.34, \mathrm{p}=0.64 ; \mathrm{df}=18 ; \mathrm{n}=144$

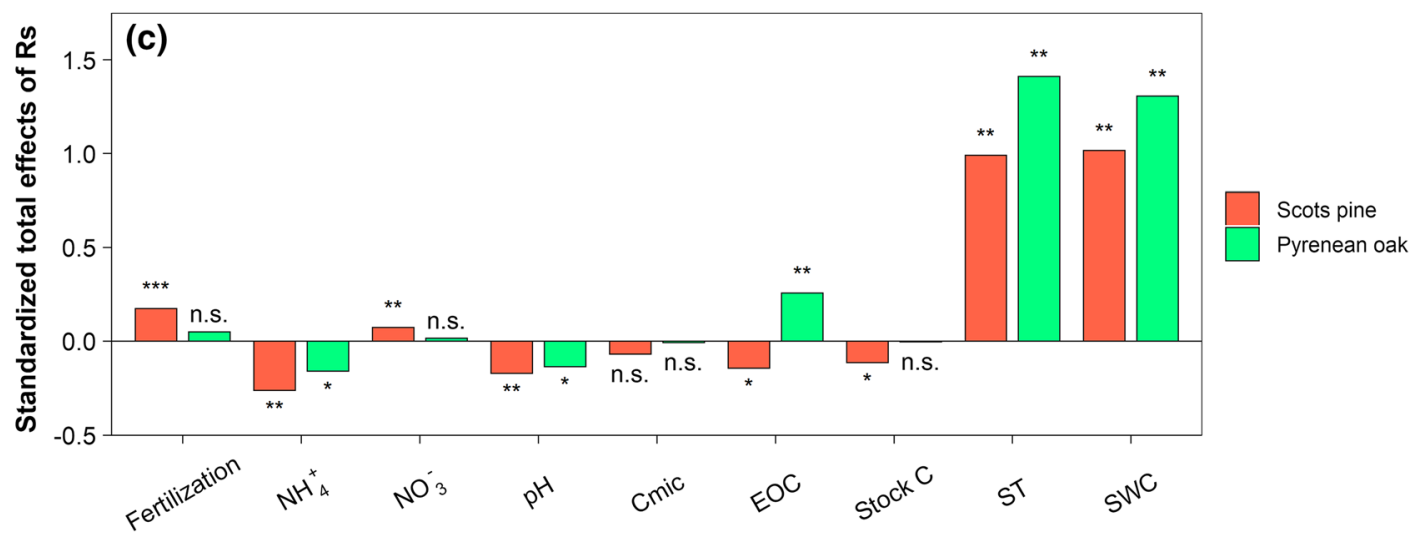

Fig. 6 Overall structural equation models for the Scots pine forest (a) and the Pyrenean oak forest (b). Values adjacent to paths indicate standardized regression weights. Only significant relationships $(\mathrm{p}<0.05)$ are depicted (see the hypothesized model in Fig. S1). Arrow widths are proportional to estimated regression weights. Squared multiple correlations $\left(R^{2}\right)$ of dependent variables are also shown. Goodness of fit statistics

small size of our plots, we suggest that the effect of our fertilization on plant growth was rather limited and we consider more plausible that the observed effects are primarily originated in changes in the heterotrophic component of $\mathrm{R}_{\mathrm{S}}$ following direct incorporation of the $\mathrm{N}$ into the soil. for each model are: NFI Bentler and Bonnett's normed fit index, GFI goodness of fit index, RMSEA root mean square error approximation. See Fig. S1 for the nomenclature used in the rectangles. c Standardized total effects (direct plus indirect effects) of tested variables on $\mathrm{R}_{\mathrm{S}}$ for each forest stand. Asterisks indicate levels of significance: $* * *$ p-value $<0.001$, **pvalue $<0.01$, *p-value $<0.05$, n.s. non-significant

Short-term soil response to enhanced $\mathrm{N}$ availability

In Mediterranean forests, dry $\mathrm{N}$ deposition dominates and tends to accumulate on soil and plant surfaces (Fenn et al. 2003; Ochoa-Hueso et al. 2011), so that, seasonal rains may induce enhanced inorganic $\mathrm{N}$ availability affecting soil attributes and $R_{S}$. In our experiment, we only detected a pulse in $\mathrm{R}_{\mathrm{S}}$ (at the oak 
forest) that was associated to the spray of water and not to higher $\mathrm{N}$ availability, since it also occurred in the control plots (Fig. 5). However, we observed a full range of short-term changes in other soil chemical and biological properties for both investigated tree species $24 \mathrm{~h}$ after fertilization (Fig. 2).

In line with our hypotheses, there was a positive relationship between the $\mathrm{NO}_{3}{ }^{-}$concentrations in soils and the $\mathrm{N}$-fertilization rates, subsequently leading to soil acidification and decreased microbial biomass $\mathrm{C}$ (Knorr et al. 2005; Zhou et al. 2014; Riggs and Hobbie 2016). The higher soil $\mathrm{NO}_{3}{ }^{-}$concentration with high $\mathrm{N}$ fertilization doses is associated with base cation leaching (Bobbink et al. 2010; Cusack et al. 2016; Li et al. 2018), which may explain the lower concentrations of $\mathrm{K}^{+}$and lower soil $\mathrm{pH}$ values we found in highfertilized plots when compared to the control or the medium-fertilization treatment. Further, $\mathrm{N}$ addition is linked to decreases in microbial activity, which usually elevates EOC levels (Waldrop and Zak 2006; Zak et al. 2008; Liu and Greaver 2010). On the other hand, enhanced microbial nitrification and its subsequent acidification effect have been related to a decline of EOC (Evans et al. 2008). In our study, it seems that the effect of acidification dominated over the impact of reduced soil microbial activity on EOC, especially in soils under pine that were already slightly more acidic than under oak prior to the manipulation experiment (4.3 vs. 5.1 soil $\mathrm{pH}$ in pine and oak, respectively).

The addition of $\mathrm{N}$ to the soil induced a $25 \%$ reduction of microbial biomass $\mathrm{C}$ in the top $10 \mathrm{~cm}$ of the soil in the pine forest and $15 \%$ reduction in the oak forest. To match these observations with the lack of responses of fertilization on $\mathrm{R}_{\mathrm{S}}$ (Fig. 4), a strong decrease in CUE had to occur, as shown by the increase in $\mathrm{qCO}_{2}$ (i.e. a lower use of $\mathrm{C}$ for growth favouring $R_{S}$, Sinsabaugh et al. 2013; Fig. 3). In the short-term and especially in N-limited ecosystems, the alleviation of $\mathrm{N}$ constraints on microbial activity with inorganic $\mathrm{N}$ supply may increase the demand for labile $\mathrm{C}$ due to increases in cellulose-degrading enzymes and decreases in lignin-degrading enzymes (Waldrop and Zak 2006; Janssens et al. 2010; Liu and Greaver 2010). In both forests, the displayed $\mathrm{qCO}_{2}$ trend among $\mathrm{N}$ treatments (i.e. medium-fertilization $\geq$ high-fertilization $\geq$ control) suggests the existence of a threshold in the cumulative amounts of $\mathrm{N}$ that shift soil properties and functioning (Lo Cascio et al. 2017). In these acidic soils, where the exchangeable base pool is presumably smaller than the total exchangeable acidity, the base cation losses with heavy $\mathrm{N}$ loads within several decades could lead to soil acidification (Reuss and Johnson 1986; Janssens et al. 2010) and negative effects on microbial and plant activity (DeForest et al. 2004; Sinsabaugh et al. 2008).

\section{Long-term perspective}

The observed moderate response of $R_{S}$ upon increased $\mathrm{N}$ deposition is probably due not only to the Mediterranean environmental conditions, but also to the relatively lower background atmospheric $\mathrm{N}$ deposition rates $\left(10-15 \mathrm{~kg} \mathrm{~N} \mathrm{ha}^{-1} \mathrm{a}^{-1}\right)$ compared to other forest ecosystems in Central Europe (up to $38 \mathrm{~kg} \mathrm{~N}^{-1}$ $\mathrm{a}^{-1}$, Pilegaard et al. 2006). While average $\mathrm{N}$ atmospheric deposition rates have declined since the 1990s by $30-50 \%$ in Central and Western Europe, southwestern Europe shows increases in throughfall $\mathrm{N}$ deposition rates larger than $30 \%$ (Schmitz et al. 2019) as well as increases in $\mathrm{NO}_{\mathrm{x}}$ emissions (Fagerli and Aas 2008). Our study investigated the effects over 3 years only; and our observations fit in the first stages of $\mathrm{N}$ ecosystem enrichment following increases in $\mathrm{N}$ deposition (Aber et al. 1998). Despite the modest response of $R_{S}$ following fertilization, the observed acidification, the loss of base cations and the decreased soil microbial biomass in the short-term suggest that stronger effects in the belowground $\mathrm{C}$ and $\mathrm{N}$ cycles may occur with further increases in $\mathrm{N}$ enrichment.

\section{Conclusions}

The $R_{S}$ showed a high resilience to 3 years of soil $\mathrm{N}$ enrichment in this Mediterranean ecotone forest. Our results suggest the characteristic seasonal variability of soil moisture and temperature as the main factors constraining and modulating the $\mathrm{R}_{\mathrm{S}}$ response to $\mathrm{N}$ additions. We further propose a hierarchy on drivers modulating the $\mathrm{R}_{\mathrm{S}}$ response by which, when appropriate microclimatic conditions occur, soil $\mathrm{N}$ statusas shown by soil stoichiometry along with inorganic $\mathrm{N}$ contents-becomes more relevant. Hence, the more $\mathrm{N}$-limited soil beneath the Scots pine showed higher $\mathrm{R}_{\mathrm{S}}$ sensitivity to increased $\mathrm{N}$ availability, with the medium-fertilization rates increasing $R_{S}$ compared to the control treatment, than the Pyrenean oak forest. 
Moreover, the short-term negative changes on soil properties observed in these acidic soils-e.g. soil acidification, the loss of base cations and reduced microbial biomass, emphasizes the need to investigate whether these effects persist in the long run, and what would be their consequences for the belowground $\mathrm{C}$ and $\mathrm{N}$ cycles.

Acknowledgements We wish to thank Marta Rivas for her invaluable assistance during measurement campaigns and for her help in the laboratory analysis, and Fertiberia for providing the fertilizer. We also acknowledge Adrián Escudero (URJC, Area of Biodiversity and Conservation) for his explanations and recommendations regarding the structural equation modelling.

Author contributions AR acquired the funds. AR and MJFA conceptualized and designed the experiment. MJFA carried out the investigation and methodology. MJFA and EDP drafted and wrote the manuscript. All authors reviewed and edited the manuscript.

Funding Open access funding provided by University of Natural Resources and Life Sciences Vienna (BOKU). This work has been partially funded by the Madrid Regional Government with the REMEDINAL-TE-CM (S2018-4338) Project and by the Spanish Government with the FORADMIT Project (AGL2016-77863-R). EDP received funds from the Austrian Climate Research Program, 12th Call (KR19AC0K17557, "EXAFOR"). MJFA received funds from the Fundação para a Ciência e Tecnologia, Portuguese Ministry of Science, Technology, and Higher Education, through national funds and COMPETE 2020 (Projects POCI-01-0145-FEDER030231 I PTDC/BIA-ECO/30231/2017, "UNDERCLIME" and UIDB/04004/2020).

Data availability Primary data of this study is openly available in https://doi.org/10.6084/m9.figshare.13582748.v1 (Fernández-Alonso et al. 2021).

Code availability Code used in this manuscript is available upon request.

\section{Declarations}

Conflict of interest Authors declare that there is no actual or potential conflict of interest in relation to this article.

\section{Open Access}

\section{References}

Aber JD, McDowell WH, Nadelhoffer K et al (1998) Nitrogen saturation in temperate forest ecosystems-hypothesis revisited. Bioscience 48:921-934
Almagro M, López J, Querejeta JI, Martínez-Mena M (2009) Temperature dependence of soil $\mathrm{CO}_{2}$ efflux is strongly modulated by seasonal patterns of moisture availability in a Mediterranean ecosystem. Soil Biol Biochem 41:594-605. https://doi.org/10.1016/j.soilbio.2008.12.021

Averill C, Waring B (2018) Nitrogen limitation of decomposition and decay: how can it occur? Glob Change Biol 24:1417-1427. https://doi.org/10.1111/gcb.13980

Barton K (2018) MuMIn: Multi-Model Inference. Package, version 1.43.6. https://CRAN.R-project.org/package= MuMIn

Bates D, Maechler M, Bolker B, Walker S (2015) Fitting linear mixed-effects models using lme4. J Stat Softw 67:1-48. https://doi.org/10.18637/jss.v067.i01

Bobbink R, Hicks K, Galloway JN et al (2010) Global assessment of nitrogen deposition effects on terrestrial plant diversity: a synthesis. Ecol Appl 20:30-59. https://doi.org/ 10.1890/08-1140.1

Bouwman AF, Van Vuuren DP, Derwent RG, Posch M (2002) A global analysis of acidification and eutrophication of terrestrial ecosystems. Water Air Soil Pollut 141:349-382. https://doi.org/10.1023/A:1021398008726

Browne MW, Cudeck R (1993) Alternative ways of assessing model fit. In: Bollen KA, Long JS (eds) Testing structural equation models. Sage, Thousand Oaks, pp 136-162

Creamer CA, de Menezes AB, Krull ES et al (2015) Microbial community structure mediates response of soil $\mathrm{C}$ decomposition to litter addition and warming. Soil Biol Biochem 80:175-188. https://doi.org/10.1016/j.soilbio.2014.10.008

Cusack DF, Macy J, McDowell WH (2016) Nitrogen additions mobilize soil base cations in two tropical forests. Biogeochemistry 128:67-88. https://doi.org/10.1007/s10533-0160195-7

de Vries FT, Manning P, Tallowin JRB et al (2012) Abiotic drivers and plant traits explain landscape-scale patterns in soil microbial communities. Ecol Lett 15:1230-1239. https://doi.org/10.1111/j.1461-0248.2012.01844.x

de Vries W, Solberg S, Dobbertin M et al (2009) The impact of nitrogen deposition on carbon sequestration by European forests and heathlands. For Ecol Manag 258:1814-1823. https://doi.org/10.1016/j.foreco.2009.02.034

DeForest JL, Zak DR, Pregitzer KS, Burton AJ (2004) Atmospheric nitrate deposition, microbial community composition, and enzyme activity in northern hardwood forests. Soil Sci Soc Am J 68:132-138. https://doi.org/10.2136/ sssaj2004.1320

Díaz-Pinés E (2011) Soil carbon storage in the ecotone between Scots pine (Pinus sylvestris L.) and Pyrenean oak (Quercus pyrenaica Willd.) in Central Spain. Dissertation, Universidad Politécnica de Madrid

Díaz-Pinés E, Rubio A, Montes F (2011a) Aboveground soil C inputs in the ecotone between Scots pine and Pyrenean oak in Sierra de Guadarrama. For Syst 20:485-495. https://doi. org/10.5424/fs/20112003-11083

Díaz-Pinés E, Rubio A, Van Miegroet H et al (2011b) Does tree species composition control soil organic carbon pools in Mediterranean mountain forests? For Ecol Manag 262:1895-1904. https://doi.org/10.1016/j.foreco.2011.02. 004

Díaz-Pinés E, Schindlbacher A, Godino M et al (2014) Effects of tree species composition on the $\mathrm{CO}_{2}$ and $\mathrm{N}_{2} \mathrm{O}$ efflux of a 
Mediterranean mountain forest soil. Plant Soil 384:243-257. https://doi.org/10.1007/s11104-014-2200-z

Dirnböck T, Foldal C, Djukic I et al (2017) Historic nitrogen deposition determines future climate change effects on nitrogen retention in temperate forests. Clim Change 144:221-235. https://doi.org/10.1007/s10584-017-2024-y

Escudero M, Lozano A, Hierro J et al (2016) Assessment of the variability of atmospheric pollution in National Parks of mainland Spain. Atmos Environ 132:332-344. https://doi. org/10.1016/j.atmosenv.2016.03.006

Evans CD, Goodale CL, Caporn SJM et al (2008) Does elevated nitrogen deposition or ecosystem recovery from acidification drive increased dissolved organic carbon loss from upland soil? A review of evidence from field nitrogen addition experiments. Biogeochemistry 91:13-35. https:// doi.org/10.1007/s10533-008-9256-X

Fagerli H, Aas W (2008) Trends of nitrogen in air and precipitation: model results and observations at EMEP sites in Europe, 1980-2003. Environ Pollut 154:448-461. https:// doi.org/10.1016/j.envpol.2008.01.024

Fenn ME, Baron JS, Allen EB et al (2003) Ecological effects of nitrogen deposition in the western United States. Bioscience 53:404-420. https://doi.org/10.1641/00063568(2003)053[0404:EEONDI]2.0.CO;2

Fernández-Alonso MJ, Curiel Yuste J, Kitzler B et al (2018a) Changes in litter chemistry associated with global changedriven forest succession resulted in time-decoupled responses of soil carbon and nitrogen cycles. Soil Biol Biochem 120:200-211. https://doi.org/10.1016/j.soilbio. 2018.02.013

Fernández-Alonso MJ, Díaz-Pinés E, Ortiz C, Rubio A (2018b) Disentangling the effects of tree species and microclimate on heterotrophic and autotrophic soil respiration in a Mediterranean ecotone forest. For Ecol Manag 430:533-544. https://doi.org/10.1016/j.foreco.2018.08. 046

Fernández-Alonso, MJ, Díaz-Pinés E, Rubio A (2021) Drivers of soil respiration in response to nitrogen addition in a Mediterranean mountain forests. figshare. Dataset. https:// doi.org/10.6084/m9.figshare.13582748.v1

Finney SJ, DiStefano C (2006) Non-normal and categorical data in structural equation modeling. In: Hancok GR, Mueller RO (eds) Structural equation modeling: a second course. Information Age Publishing, Greenwich, pp 269-314

Forstner SJ, Wechselberger V, Müller S et al (2019) Vertical redistribution of soil organic carbon pools after twenty years of nitrogen addition in two temperate coniferous forests. Ecosystems 22:379-400. https://doi.org/10.1007/ s10021-018-0275-8

Frey SD, Knorr M, Parrent JL, Simpson RT (2004) Chronic nitrogen enrichment affects the structure and function of the soil microbial community in temperate hardwood and pine forests. For Ecol Manag 196:159-171. https://doi.org/ 10.1016/j.foreco.2004.03.018

Galiano L, Martínez-Vilalta J, Lloret F (2010) Drought-induced multifactor decline of Scots pine in the Pyrenees and potential vegetation change by the expansion of co-occurring oak species. Ecosystems 13:978-991. https://doi. org/10.1007/s10021-010-9368-8
Galloway JN, Aber JD, Erisman JW et al (2003) The nitrogen cascade. Bioscience 53:341-356. https://doi.org/10.1641/ 0006-3568(2003)053[0341:TNC]2.0.CO;2

Galloway JN, Townsend AR, Erisman JW et al (2008) Transformation of the nitrogen cycle: recent trends, questions, and potential solutions. Science 320:889-892. https://doi. org/10.1126/science. 1136674

García-Gómez H, Garrido JL, Vivanco MG et al (2014) Nitrogen deposition in Spain: modeled patterns and threatened habitats within the Natura 2000 network. Sci Total Environ 485-486:450-460. https://doi.org/10.1016/j.scitotenv. 2014.03.112

Gruber N, Galloway JN (2008) An Earth-system perspective of the global nitrogen cycle. Nature 451:293-296. https://doi. org/10.1038/nature06592

Högberg P, Fan H, Quist M et al (2006) Tree growth and soil acidification in response to 30 years of experimental nitrogen loading on boreal forest. Glob Change Biol 12:489-499. https://doi.org/10.1111/j.1365-2486.2006. 01102.x

Iriondo JM, Albert MJ, Escudero A (2003) Structural equation modelling: an alternative for assessing causal relationships in threatened plant populations. Biol Conserv 113:367-377. https://doi.org/10.1016/S00063207(03)00129-0

IUSS Working Group, WRB (2015) World Reference Base for Soil Resources 2014, update 2015. International soil classification system for naming soils and creating legends for soil maps. FAO, Rome

Janssens IA, Dieleman W, Luyssaert S et al (2010) Reduction of forest soil respiration in response to nitrogen deposition. Nat Geosci 3:315-322. https://doi.org/10.1038/ngeo844

Knorr M, Frey SD, Curtis PS (2005) Nitrogen additions and litter decomposition: a meta-analysis. Ecology 86:3252-3257. https://doi.org/10.1890/05-0150

Lenth RV (2016) Least-Squares Means: the R package lsmeans. J Stat Softw 69:1-33. https://doi.org/10.18637/jss.v069.i01

Li Y, Sun J, Tian D et al (2018) Soil acid cations induced reduction in soil respiration under nitrogen enrichment and soil acidification. Sci Total Environ 615:1535-1546. https://doi.org/10.1016/j.scitotenv.2017.09.131

Liu L, Greaver TL (2010) A global perspective on belowground carbon dynamics under nitrogen enrichment. Ecol Lett 13:819-828. https://doi.org/10.1111/j.1461-0248.2010. 01482.x

Liu W, Qiao C, Yang S et al (2018) Microbial carbon use efficiency and priming effect regulate soil carbon storage under nitrogen deposition by slowing soil organic matter decomposition. Geoderma 332:37-44. https://doi.org/10. 1016/j.geoderma.2018.07.008

Lo Cascio M, Morillas L, Ochoa-Hueso R et al (2017) Contrasting effects of nitrogen addition on soil respiration in two Mediterranean ecosystems. Environ Sci Pollut Res 24:26160-26171. https://doi.org/10.1007/s11356-0178852-5

Lu M, Zhou X, Luo Y et al (2011) Minor stimulation of soil carbon storage by nitrogen addition: a meta-analysis. Agric Ecosyst Environ 140:234-244. https://doi.org/10.1016/j. agee.2010.12.010

Moreno-Fernández D, Hernández L, Sánchez-González M et al (2016) Space-time modeling of changes in the abundance 
and distribution of tree species. For Ecol Manag 372:206-216. https://doi.org/10.1016/j.foreco.2016.04. 024

Ochoa-Hueso R, Allen EB, Branquinho C et al (2011) Nitrogen deposition effects on Mediterranean-type ecosystems: an ecological assessment. Environ Pollut 159:2265-2279. https://doi.org/10.1016/j.envpol.2010.12.019

Pilegaard K, Skiba U, Ambus P et al (2006) Factors controlling regional differences in forest soil emission of nitrogen oxides ( $\mathrm{NO}$ and $\mathrm{N}_{2} \mathrm{O}$ ). Biogeosciences 3:651-661. https:// doi.org/10.5194/bg-3-651-2006

Pregitzer KS, Burton AJ, Zak DR, Talhelm AF (2008) Simulated chronic nitrogen deposition increases carbon storage in northern temperate forests. Glob Change Biol 14:142-153. https://doi.org/10.1111/j.1365-2486.2007. 01465.x

R Core Team (2019) R: a language and environment for statistical computing. R Foundation for Statistical Computing, Vienna. https://www.R-project.org/

Reuss JO, Johnson DW (1986) Acid deposition and the acidification of soils and waters. Springer, New York

Riggs CE, Hobbie SE (2016) Mechanisms driving the soil organic matter decomposition response to nitrogen enrichment in grassland soils. Soil Biol Biochem 99:54-65. https://doi.org/10.1016/j.soilbio.2016.04.023

Rousk J, Bååth E, Brookes PC et al (2010) Soil bacterial and fungal communities across a $\mathrm{pH}$ gradient in an arable soil. ISME J 4:1340-1351. https://doi.org/10.1038/ismej.2010. 58

Ruiz-Labourdette D, Nogués-Bravo D, Ollero HS et al (2012) Forest composition in Mediterranean mountains is projected to shift along the entire elevational gradient under climate change. J Biogeogr 39:162-176. https://doi.org/10. 1111/j.1365-2699.2011.02592.x

Sardans J, Rivas-Ubach A, Peñuelas J (2011) Factors affecting nutrient concentration and stoichiometry of forest trees in Catalonia (NE Spain). For Ecol Manag 262:2024-2034. https://doi.org/10.1016/j.foreco.2011.08.019

Schmitz A, Sanders TGM, Bolte A et al (2019) Responses of forest ecosystems in Europe to decreasing nitrogen deposition. Environ Pollut 244:980-994. https://doi.org/10. 1016/j.envpol.2018.09.101

Sher AA, Goldberg DE, Novoplansky A (2004) The effect of mean and variance in resource supply on survival of annuals from Mediterranean and desert environments. Oecologia 141:353-362. https://doi.org/10.1007/s00442003-1435-9

Shipley B (2004) Cause and correlation in biology. A user's guide to path analysis, structural equations and causal inference. Cambridge University Press, Cambridge

Sinsabaugh RL, Lauber CL, Weintraub MN et al (2008) Stoichiometry of soil enzyme activity at global scale. Ecol Lett 11:1252-1264. https://doi.org/10.1111/j.1461-0248.2008. 01245.x

Sinsabaugh RL, Manzoni S, Moorhead DL, Richter A (2013) Carbon use efficiency of microbial communities: stoichiometry, methodology and modelling. Ecol Lett 16:930-939. https://doi.org/10.1111/ele.12113
Søe ARB, Buchmann N (2005) Spatial and temporal variations in soil respiration in relation to stand structure and soil parameters in an unmanaged beech forest. Tree Physiol 25:1427-1436. https://doi.org/10.1093/treephys/25.11. 1427

Sun Z, Liu L, Ma Y et al (2014) The effect of nitrogen addition on soil respiration from a nitrogen-limited forest soil. Agric for Meteorol 197:103-110. https://doi.org/10.1016/j. agrformet.2014.06.010

Sutton MA, Howard CM, Erisman JW et al (2011) The challenge to integrate nitrogen science and policies: the European Nitrogen Assessment approach. In: Sutton MA, Howard CM, Erisman JW et al (eds) The European Nitrogen Assessment. Cambridge University Press, Cambridge, pp 82-96

Treseder KK (2008) Nitrogen additions and microbial biomass: a meta-analysis of ecosystem studies. Ecol Lett 11:1111-1120. https://doi.org/10.1111/j.1461-0248.2008. 01230.x

Vance ED, Brookes PC, Jenkinson DS (1987) An extraction method for measuring soil microbial biomass C. Soil Biol Biochem 19:703-707. https://doi.org/10.1016/00380717(87)90052-6

Waldrop MP, Zak DR (2006) Response of oxidative enzyme activities to nitrogen deposition affects soil concentrations of dissolved organic carbon. Ecosystems 9:921-933. https://doi.org/10.1007/s10021-004-0149-0

Ximénez de Embún J (1977) El monte bajo. Ministerio de Agricultura, Madrid

$\mathrm{Xu}$ M, Qi Y (2001) Soil-surface $\mathrm{CO}_{2}$ efflux and its spatial and temporal variations in a young ponderosa pine plantation in northern California. Glob Change Biol 7:667-677. https:// doi.org/10.1046/j.1354-1013.2001.00435.x

Zak DR, Holmes WE, Burton AJ et al (2008) Simulated atmospheric $\mathrm{NO}_{3}{ }^{-}$deposition increases soil organic matter by slowing decomposition. Ecol Appl 18:2016-2027

Zhang C, Niu D, Hall SJ et al (2014) Effects of simulated nitrogen deposition on soil respiration components and their temperature sensitivities in a semiarid grassland. Soil Biol Biochem 75:113-123. https://doi.org/10.1016/j. soilbio.2014.04.013

Zhong Y, Yan W, Shangguan Z (2016) The effects of nitrogen enrichment on soil $\mathrm{CO}_{2}$ fluxes depending on temperature and soil properties. Glob Ecol Biogeogr 25:475-488. https://doi.org/10.1111/geb.12430

Zhou L, Zhou X, Zhang B et al (2014) Different responses of soil respiration and its components to nitrogen addition among biomes: a meta-analysis. Glob Change Biol 20:2332-2343. https://doi.org/10.1111/gcb.12490

Zhu C, Ma Y, Wu H et al (2016) Divergent effects of nitrogen addition on soil respiration in a semiarid grassland. Sci Rep 6:33541. https://doi.org/10.1038/srep33541

Publisher's Note Springer Nature remains neutral with regard to jurisdictional claims in published maps and institutional affiliations. 